\title{
Keratoacanthoma associated with cutaneous horn manifestation: case report and difficulty of diagnosis
}

\begin{abstract}
- Marina Curra Departament of Oral Pathology, Dentistry School, Federal University of Rio Grande do Sul, Porto Alegre, RS, Brazil • Marco Antonio Trevizani Martins Service of Stomatology, Clinical Hospital of Porto Alegre, Federal University of Rio Grande do Sul, Porto Alegre, RS, Brazil • Laura Campos Hildebrand Departament of Oral Pathology Dentistry School Federal University of Rio Grande do Sul, Porto Alegre, RS, Brazil • Maria Cristina Munerato Service of Stomatology Clinical Hospital of Porto Alegre, Federal University of Rio Grande do Sul, Porto Alegre, RS, Brazil • Manoel Sant'Ana Filho Departament of Oral Pathology, Dentistry School, Federal University of Rio Grande do Sul, Porto Alegre, RS, Brazil • Manoela Domingues Martins Departament of Oral Pathology, Dentistry School, Federal University of Rio Grande do Sul, Porto Alegre, RS, Brazil
\end{abstract}

ABSTRACT | Background: Cutaneous horn (CH) is a conical hyperkeratotic projection of skin with keratotic material. A broad variety of lesions may be found with clinical aspect of cutaneous horn, including malignant tumors. Case report: We report a case of a 77-year-old male patient, presenting an asymptomatic lesion with clinical aspect of $\mathrm{CH}$ in the lower lip. The clinical diagnosis hypothesis was squamous cell carcinoma (SCC) and an incisional biopsy was performed. The histopathological analysis revealed a keratoacantoma (KA) and the lesion was completely removed. The two year follow-up revealed no recurrence. Discussion: $\mathrm{CH}$ is rarely accompanied by KA. However, KA shows a greater degree of nuclear atypia than SCC, making the differentiation of the two diseases very difficult. This case highlights the importance of histopathological examination to rule out malignancy.

DESCRIPTORS | Neoplasms; Keratoacanthoma; Squamous Cell Carcinoma.

RESUMO | Ceratoacantoma associado a manifestação de corno cutâneo: relato de caso e dificuldade de diagnóstico • Introdução: O corno cutâneo (CC) é uma projeção hiperceratótica cônica da pele. Uma ampla variedade de lesões pode ser encontrada com aspecto clínico de corno cutâneo, incluindo tumores malignos. Relato de caso: Relatamos um caso de paciente do sexo masculino, 77 anos de idade, apresentando uma lesão assintomática, com aspecto clínico da CC no lábio inferior. A hipótese de diagnóstico clínico foi de carcinoma espinocelular (CEC) e uma biópsia incisional foi realizada. A análise histopatológica revelou um ceratoacantoma e a lesão foi completamente removida. Em um ano de acompanhamento nenhuma recidiva foi observada. Discussão: CC raramente é acompanhada por ceratoacantoma. No entanto, ceratoacantoma mostra um maior grau de atipia nuclear do que CEC tornando a diferenciação de duas doenças muito difícil. Neste caso ressaltamos a importância do exame histopatológico para descartar malignidade.

DESCRITORES | Neoplasias; Ceratoacantoma; Carcinoma Espinocelular.

CORRESPONDING AUTHOR
- Manoela Domingues Martins Department of Oral Pathology, Dentistry School, Federal University of Rio Grande do Sul • R. Ramiro Barcelos, 2492, Santa Cecília Porto Alegre, RS, Brazil • 90035-003 Email: manomartins@gmail.com

- Received Aug 2, 2015 • Accepted Sep 18, 2015

- Dol http://dx.doi.org/10.11606/issn.2357-8041.clrd.2015.123074 


\section{INTRODUCTION}

Cutaneous horn is a clinical term for describing the hyperproliferation of compact keratin that may arise from a wide range of benign and malignant epidermal tumors. ${ }^{1-4}$ The incidence of $\mathrm{CH}$ on a benign lesion as keratoacanthoma (KA) is very rare. ${ }^{2}$ This study aimed to describe a case report of KA in lower lip associated with a $\mathrm{CH}$ and discuss the difficulty to establish the diagnosis.

\section{CASE REPORT}

A 77-year-old male patient presenting an asymptomatic tumor in the lower lip with a one-month history was submitted to evaluation. The clinical examination revealed an exuberant, nodular, sessile tumor with brownish and blackish coloration, measuring $30 \times 20 \times 15 \mathrm{~mm}$ (Figure 1A). Upon palpation, the tumor was firm and quite infiltrative in the lip mucosa. Based on the clinical features, the diagnostic hypothesis was $\mathrm{CH}$. Incisional biopsy was performed under local anesthesia (Figure 1B), followed by histopathological analysis. Histologic sections revealed a hyperplastic epithelium with interconnecting groups of well-differentiated squamous cells surrounded by connective tissue. In some areas, the formation of keratin pearls and keratinization of individual cells were observed (Figure 2). The epithelial basal layer was intact and no dysplasia was detected. Diffusely scattered lymphocytic infiltrate was found in the underlying submucosal fibrous connective tissue (Figure 3). From these characteristics, the diagnosis of KA was established and the surgical excision was performed. The histopathologic analysis of the entire specimen confirmed the diagnosis: keratin hyperproliferation in the central area, keratin pearls in deeper layers of the epithelium (Figure 4A), proliferation into the connective tissue without invasion and not exceeding the limit of the underlying muscle, maintenance of the basal layer, and chronic inflammatory response (Figure 4B). The patient was reassessed after two years and no signs of recurrence were observed. The patient is currently in clinical follow up (Figure $5 \mathrm{~A}$ and B).

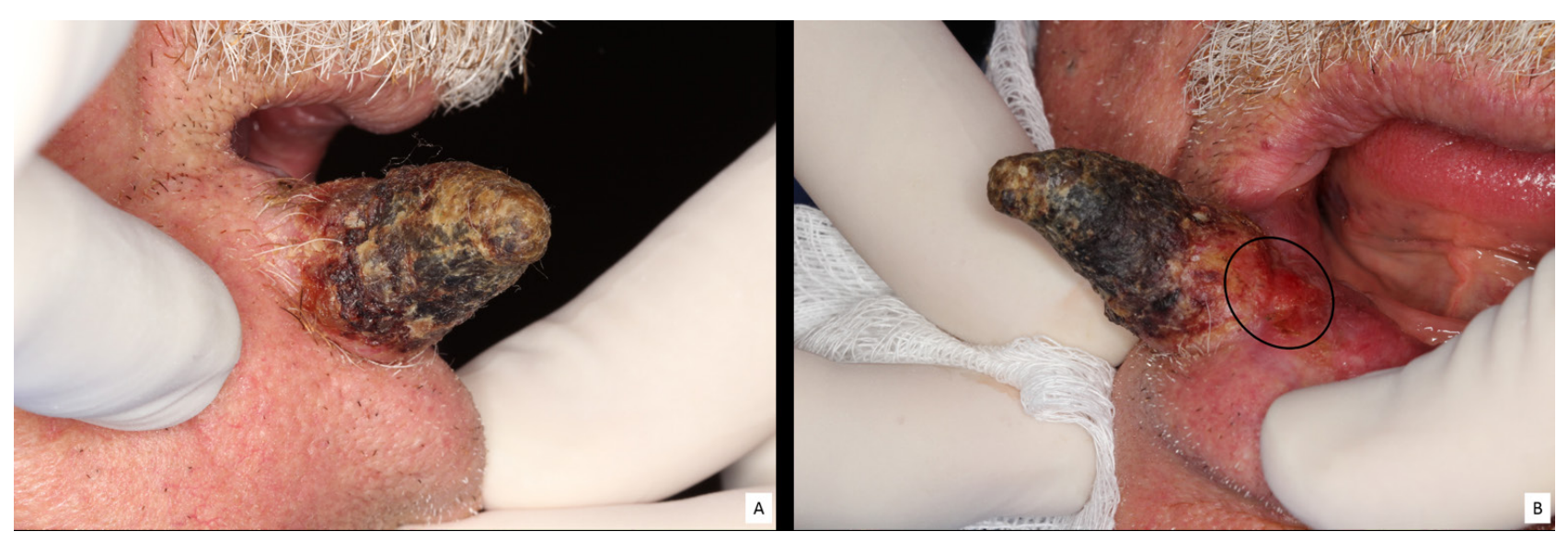

Figure 1 | Clinical appearance. A: Nodular tumor situated on lower lip exhibiting sessile base and brownish-blackish coloration. B: Incisional biopsy performed on edge (black circle). 


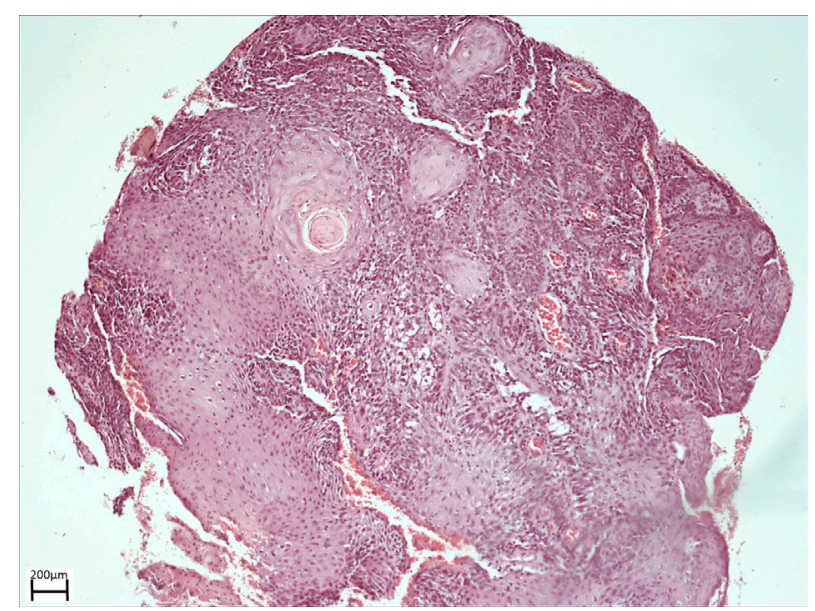

Figure 2 | Histopathological aspects of incisional biopsy; Note the acanthotic proliferation of well-differentiated stratified squamous epithelium that merged with the underlying connective tissue (hematoxylin and eosin stain; original magnification: 100x). Formation of keratin pearls and some degree of dyskeratosis were observed.

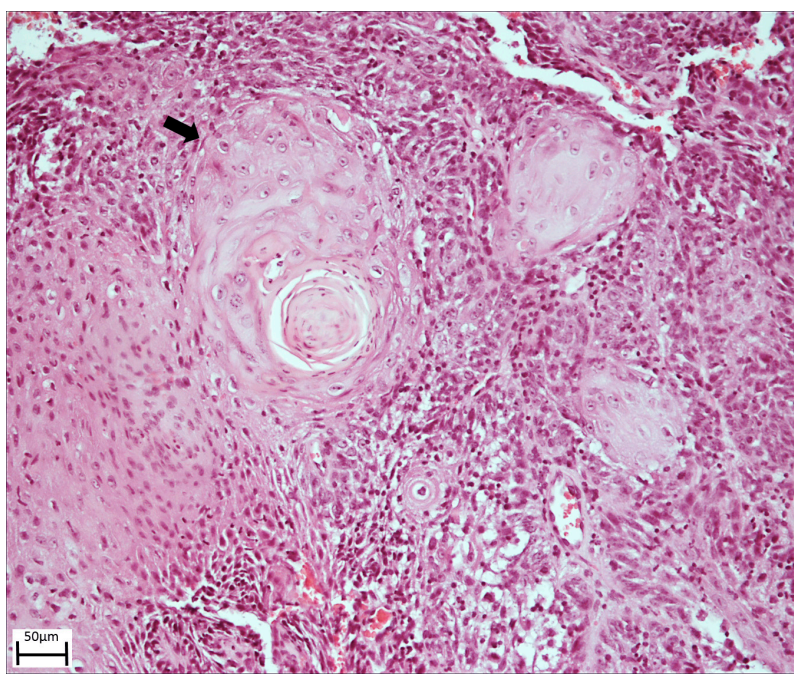

Figure 3 | Intact epithelial basal layer (black arrow) and cells without pleomorphism (hematoxylin and eosin stain; original magnification: 200x).

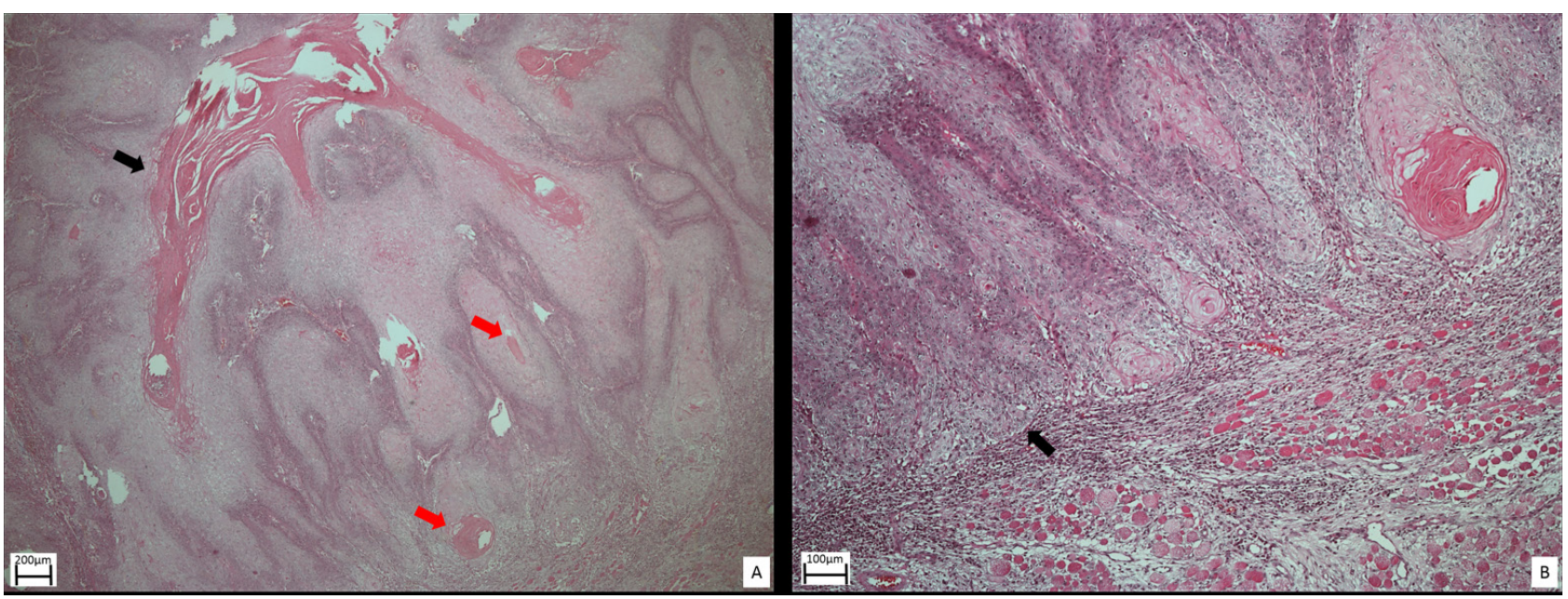

Figure 4 || Histopathological appearance of excisional biopsy. A: Keratin hyperproliferation in central area (black arrow) and keratin pearls in deeper layers of epithelium (red arrows). B: KA with proliferation into connective tissue without invasion and not exceeding limit of underlying muscle; Maintenance of basal layer (black arrow) associated with adjacent chronic inflammatory infiltrate. 


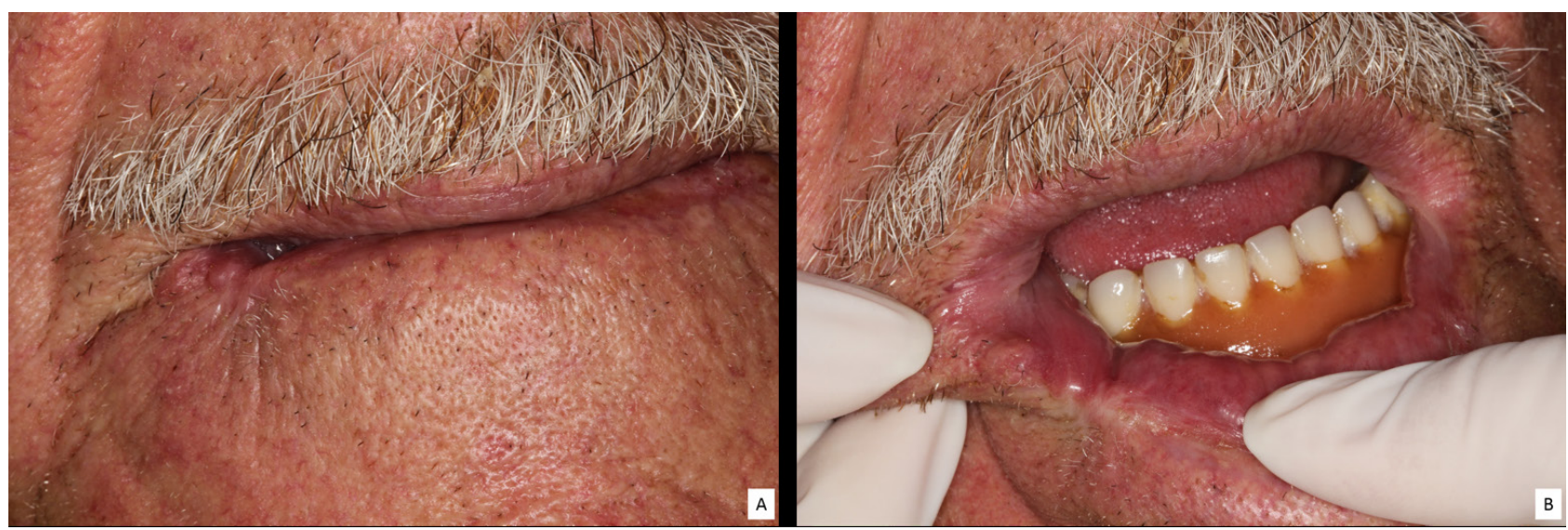

Figure 5 | Clinical appearance one year after treatment. A, B: extraoral and intraoral examinations with no signs of recurrence.

\section{DISCUSSION}

KA is a benign, proliferative, epithelial tumor that arises from hair follicles, ${ }^{5-7}$ but its etiology is unknown. ${ }^{8}$ Exposure to solar rays has been implicated in its pathogenesis, since such tumors appear in exposed areas in approximately $90 \%$ of cases..$^{-7}$ Clinically, KA is an exophytic mass that exhibits rapid growth (six to 12 weeks). KA develops in three phases: proliferative, mature, and involution. Rapid growth occurs in the first stage. ${ }^{5,9}$ The second stage is characterized by stabilization and a regression of the tumor is observed in the third stage, leaving a scar with an area of depression. ${ }^{9}$

The histopathological differentiation should be performed with squamous cell carcinoma (SCC), as both tumors have similar clinical and histopathological characteristics. KA can be histologically aggressive during early development, but it regresses over time, indicating benign behavior. ${ }^{10}$ The histological aspects of KA reveal mature cells, considerable dyskeratosis, and keratin pearls. The surface epithelium on the lateral edge of the tumor seems normal, but the epithelium at the base of the crater proliferates downward. KA causes an intense, chronic, and inflammatory cell response. All these features make KA and SCC very similar.5,6 The microscopic examination of the incisional biopsy in the present case revealed the acanthotic proliferation of well-differentiated epithelium with the formation of keratin pearls, which are common features of SCC. However, the basal layer was intact. Moreover, the epithelial cells had not invaded the connective tissue and exhibited both uniformity and monotony (Figure 3).

The manifestation of a giant $\mathrm{CH}$ on KA is very rare - only one case involving the face is reported in the literature. ${ }^{2} \mathrm{CH}$ has been reported in exposed areas of skin, but the lower lip is a very rare location. ${ }^{3}$ Regarding the underlying diseases in which cutaneous horns appear, malignant tumors are more common than benign tumors. ${ }^{4}$

KA generally heals spontaneously and leaves a scar. However, its rapid growth causes tissue destruction. Thus, the treatment of choice is complete surgical excision, ${ }^{2}$ although some authors have described the use of cryotherapy, electrodissection and curettage, radiation therapy, $\mathrm{CO}_{2}$ laser surgery, intra-tumor or topical treatment with 5 -fluoracil, corticosteroid, and methotrexate. All these treatments are indicated for small tumors. ${ }^{5}$

This study described a rare case of a patient with a giant cutaneous horn in the lower lip and discussed the importance of the histological evaluation to the definition of the final diagnosis of KA, which is 
generally a considerably difficult task, as the main differential diagnosis is a malignant tumor (SCC).

\section{REFERENCES}

1. Jones T, Blanco-Guzman M. A cutaneous horn - benign or malignant? J Craniomaxillofac Surg. 2013 Mar;41(2):144-6. doi: http://dx.doi.org/10.1016/j.jcms.2012.06.007.

2. Yang JH, Kim DH, Lee JS, Cho MK, Lee SH, Lee SY, et al. A case of cutaneous horn orinating from keratoacanthoma. Ann Dermatol. 2011 Feb;23(1): 89-91. doi: 10.5021/ad.2011.23.1.89.

3. Skoulakis C, Theos E, Chlopsidis P, Manios AG, Feritsean A, Papadakis CE. Giant cutaneous horn on squamous cell carcinoma of the lower lip. Eur J Plast Surg. 2009 Oct;32(5):257-9. doi:10.1007/s00238-009-0338-3.

4. Stavroulaki P, Mal RK. Squamous cell carcinoma presenting as a cutaneous horn. Auris Nasus Larynx. 2000 Jul;27(3):2779. doi: http://dx.doi.org/10.1016/so385-8146(oo)ooo6o-2.

5. Chauhan A, Chaudhary S, Agnihotri PG, Aadithya B. A solitary crateriform ulcer of the lower lip: a case report with review of literature. Indian J Dermatol. 2011 Jul;56(4):435-8. doi: 10.4103/0019-5154.84755.
6. Gahona MLE, Machado Filho CAS. Spontaneous involution of keratoacanthoma, iconographic documentation and similarity with volcanos of nature. An Bras Dermatol. 2012; Mar-Apr;87(2):335-6. doi: http://dx.doi.org/10.1590/So36505962012000200031.

7. Gulati S, Pandiar D, Kakky S, Jiwane AY, Balan A. Keratoacanthoma of upper lip: review and report of case managed surgically. J Clin Diagn Res. 2015 Oct;9(10): ZDo8-10. doi: 10.7860/JCDR/2015/13883.6620.

8. Wagner VP, Martins MD, Dillenburg CS, Meurer L, Castilho RM, Squarize CH. Histogenesis of keratoacanthoma: histochemical and immunohistochemical study. Oral Surg Oral Med Oral Pathol Oral Radiol. 2015 Mar;119(3):310-7. doi: 10.1016/j.0000.2014.10.006.

9. Bansal M, Manchanda K, Pandey SS. Verrucous cell carcinoma arising from an underlying giant keratoacanthoma. Int J Low Extrem Wounds. 2012 Jun;11(2):85-7. doi: 10.1177/1534734612446641.

10. Gibson-Corley KN, Rogers LM, Goeken A, Dupuy AJ, Meyerholz DK. Keratoacanthoma pathobiology in mouse models. Diseases. 2014 May;2(2):106-19. doi: 10.339o/diseases2020106. 